\title{
Anaplasma species of veterinary importance in Japan
}

Adrian Patalinghug Ybañez ${ }^{1}$ and Hisashi Inokuma²

1. Biology and Environmental Studies Program, Sciences Cluster, University of the Philippines Cebu, Lahug, Cebu City 6000, Philippines; 2. Department of Veterinary Clinical Science, Obihiro University of Agriculture and Veterinary Medicine, Obihiro, Inada Cho, Hokkaido 080-8555, Japan.

Corresponding author: Adrian Patalinghug Ybañez, e-mail: dr.adrianpybanez@gmail.com, HI: inokuma@obihiro.ac.jp

Received: 14-06-2016, Accepted: 28-09-2016, Published online: 04-11-2016

doi: 10.14202/vetworld.2016.1190-1196 How to cite this article: Ybañez AP, Inokuma H (2016) Anaplasma species of veterinary importance in Japan, Veterinary World, 9(11): 1190-1196.

\begin{abstract}
Anaplasma species of the family Anaplasmataceae, order Rickettsiales are tick-borne organisms that can cause disease in animals and humans. In Japan, all recognized species of Anaplasma (except for Anaplasma ovis) and a potentially novel Anaplasma sp. closely related to Anaplasma phagocytophilum have been reported. Most of these detected tickborne pathogens are believed to be lowly pathogenic in animals in Japan although the zoonotic A. phagocytophilum has recently been reported to cause clinical signs in a dog and in humans. This review documents the studies and reports about Anaplasma spp. in Japan.
\end{abstract}

Keywords: Anaplasma spp., Japan, tick-borne pathogen.

\section{Introduction}

Anaplasma species are Gram-negative, obligate intracellular bacteria of the order Rickettsiales, family Anaplasmataceae. These bacteria are transmitted by ticks. Currently, there are six recognized species under this genus: Anaplasma ovis, Anaplasma marginale, Anaplasma centrale, Anaplasma platys, Anaplasma bovis, and Anaplasma phagocytophilum (Figure-1) [1-3]. All of these species have been reported in Japan except for $A$. ovis, which is an intraerythrocytic bacteria that may infect goats, sheep [4], and cattle [5]. A. ovis has been reported in wildlife, including reindeer (Rangifer tarandus) [6] and European roe deer (Capreolus capreolus) [3] in other countries. As Japan has an increasing deer population, it may be worthwhile to attempt to specifically detect this pathogen because it can be pathogenic in the deer species $[5,6]$. On the other hand, recent reports on Anaplasma or Ehrlichia spp. infections in dogs in Japan remained low (1.5\%) [7], similar to previous findings $(1.1 \%)$ of Sakamoto et al. [8] but lower than the findings (7.5\%) of Inokuma et al. [9].

Results from previous studies have suggested the presence of a potentially novel Anaplasma sp. closely related to $A$. phagocytophilum in Japan (herein referred to as Anaplasma sp. Japan) due to the low 16S rRNA gene identities and phylogenetic divergence of the detected bacterium with registered

Copyright: Ybañez and Inokuma, Open Access. This article is distributed under the terms of the Creative Commons Attribution 4.0 International License (http://creativecommons.org/licenses/ by/4.0/), which permits unrestricted use, distribution, and reproduction in any medium, provided you give appropriate credit to the original author(s) and the source, provide a link to the Creative Commons license, and indicate if changes were made. The Creative Commons Public Domain Dedication waiver (http:// creativecommons.org/publicdomain/zero/1.0/) applies to the data made available in this article, unless otherwise stated.
A. phagocytophilum sequences [10-15]. Phylogenetic inferences have suggested that 2 clades exist within the genus Anaplasma: (1) Erythrocytic (A. marginale, $A$. ovis, A. centrale) and (2) leukocytic ( $A$. bovis, A. phagocytophilum, A. platys, Anaplasma sp. Japan) [3]. In this review, studies on Anaplasma species detected in Japan are briefly summarized.

\section{A. marginale}

A. marginale, the most common etiologic agent of bovine anaplasmosis, is endemic worldwide especially in tropical and subtropical areas [16]. This pathogen can be detected by peripheral blood smear and molecular means $[17,18]$ and can be genetically diverse [19]. It mainly affects cattle [20,21], causing mild to severe febrile hemolytic anemia that can result in considerable economic losses to both dairy and beef industries [1,22]. It is transmitted biologically by ticks (e.g.: Dermacentor andersoni, Rhipicephalus (Boophilus) microplus) [1] although it can also be transmitted mechanically by blood-contaminated mouthparts of biting flies and mosquitoes [23]. Erythrocytes are the major sites of infection in cattle [22], in which $A$. marginale may be seen near the margins of the infected cell. A. marginale can be transmitted transplacentally from dam to calves [24]. A. marginale was previously distributed only in the Okinawa Prefecture [25] although an outbreak was reported in imported cattle in Tokyo in 1989 [26]. Detection of $A$. marginale DNA fragments in Japan was last reported in a Japanese black cow in Okinawa in 2009, which was 13 years after eradication of R. (Boophilus) microplus [25]. It was believed that the cow was persistently infected after it was first exposed when it was still a calf. Since then, there have been no detection reports of the pathogen in Japan. It is apparent that are no more viable tick vectors that can transmit this pathogen in the country. Recent studies 


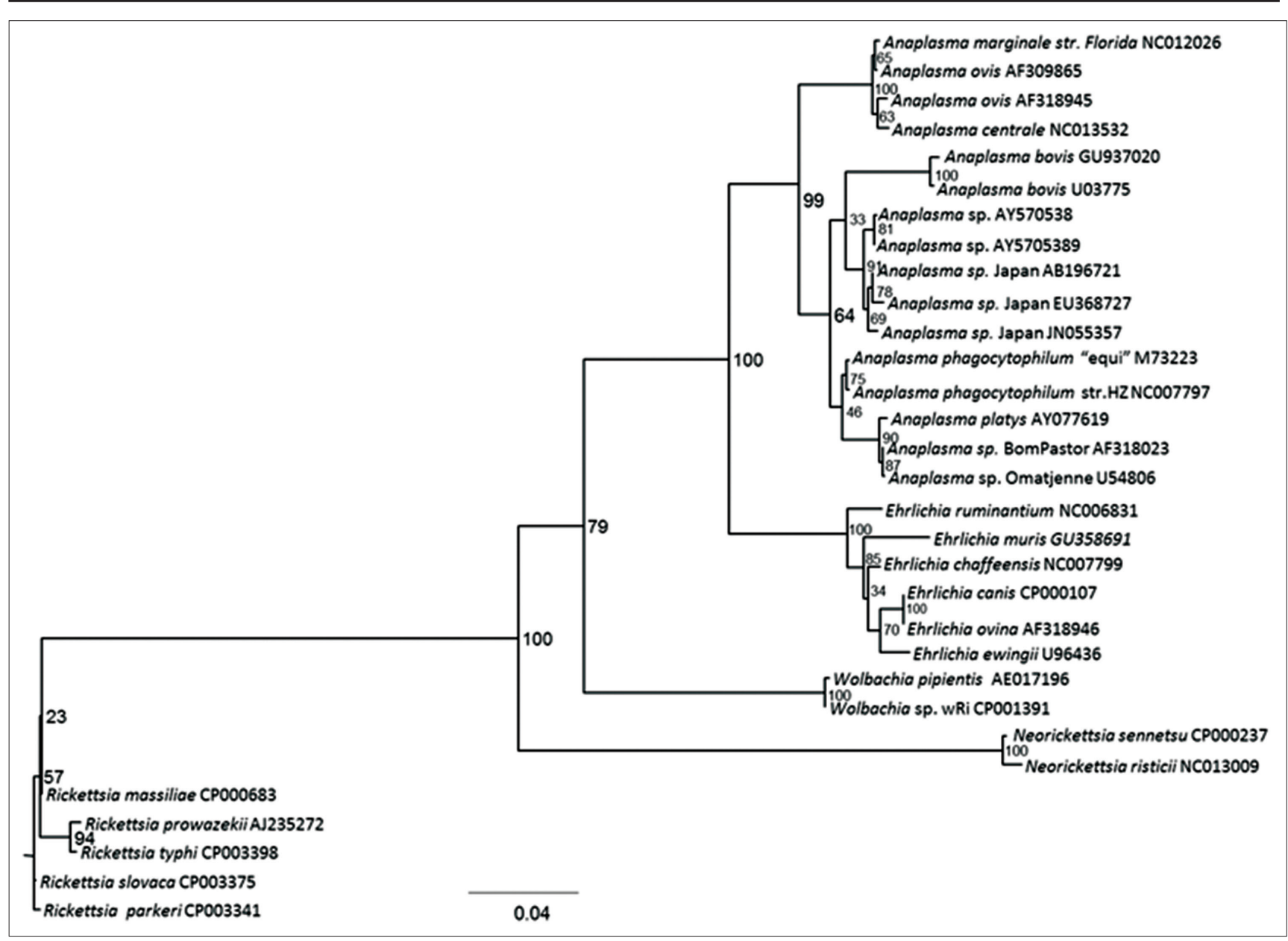

Figure-1: Phylogenetic tree of Anaplasma spp. based on the 16S rRNA gene using maximum likelihood. Rickettsia parkeri was set as the out group [3].

on ticks present in the country reported several species which are not known to be capable of transmitting A. marginale [27].

The protein composition and epitope sites of A. marginale in Japan are already analyzed $[28,29]$. It has also been molecularly characterized based on the major surface protein 1 alpha (MSP1a) wherein 4 tandem repeats that are unique to the Japanese strain were found [25]. Using the 16S rRNA and heat shock operon (groEL) genes [25], DNA fragments of Japanese A. marginale were found 100\% identical to Taiwanese (JQ321376), Chinese (DQ341369), American (CP000030, AF311303, AF309866) and Australian (AF414874, CP006846-7) strains, and 99.9\% identical with Australian (CP006846-7, AF414860) and Israel (AF414861-2), respectively. Due to high similarities, it was expected that Japanese A. marginale strain would group together with the strains from other countries in the phylogenetic analyses using the two genes.

While several countries have progressed in the development of detection tools and vaccines against A. marginale, recent researches about this pathogen in Japan have been limited, specifically detection methods using the heat shock operon (groESL) and MSP5 genes [17,21].

\section{A. platys}

A. platys is known to infect platelets in dogs [30], causing a disease called canine cyclic thrombocytopenia. It is believed to be transmitted by the brown dog tick Rhipicephalus sanguineus [31,32]. Brown dog ticks ( $R$. sanguineus) and dogs that were seropositive and/or PCR positive with $A$. platys have been reported in Fukushima, Miyazaki, Kagoshima, Ishigaki, Yamaguchi and Okinawa, and Japan [9,31,33-36]. Although observation of $A$. platys inclusion bodies in the peripheral blood platelets was reported [9], positive dogs did not show any obvious clinical sign that was suggestive of the infection [37]. To date, there are no clinical reports suggesting active clinical infection caused by this pathogen in dogs in Japan.

\section{A. centrale}

A. centrale is an intraerythrocytic tick-borne rickettsia of cattle that has a different morphology and virulence compared to A. marginale. Although severe disease may also occur with $A$. centrale, it can cause asymptomatic or paucisymptomatic infections [22], or only a mild anemia in most cases $[1,34]$. A. centrale is used for extensive vaccination of cattle against A. marginale infection in endemic areas [22]. Using microscopy, A. centrale inclusions appear centrally 
located [38]. Similar to $A$. marginale, there have been no recent detection reports of $A$. centrale in Japan, except in wild deer and Haemaphysalis longicornis ticks $[39,40]$. Sequence identities of the Japanese $A$. centrale (Aomori) have been shown to have the lowest similarities with other $A$. centrale strains [41], suggesting that it may not be $A$. centrale. Using registered $A$. centrale sequences, phylogenetic analyses using the Bayesian method revealed the possible divergence of the Japanese A. centrale. This was also confirmed using newly obtained partial groESL sequences (unpublished data). Based on the citrate synthase gene $(g l t A), A$. centrale from Japan shares a similarity of only $74.5 \%$ to the only other registered A. centrale sequence (CP001759) from Israel (vaccine strain). Recently, A. central has been shown to be prevalent in wild sika deer in Shizuoka Prefecture, Japan [42].

\section{A. bovis}

A. bovis often infects circulating monocytes $[1,2]$ and tissue macrophages of cattle in Africa, Asia, South America, and some of the Caribbean Islands [42]. While $A$. bovis infections are rare [43], they have been reported in the Middle East, and Sri Lanka [1]. DNA fragments of this pathogen have also been detected in several animals in Japan including deer, raccoons, dogs, domestic cats, Hokkaido brown bear, cattle, and Japanese wildcats $[8,10,39,40,44-50]$. The role of these animals as a natural carrier of $A$. bovis needs to be clarified. On the other hand, the documented tick vector in Japan wherein $A$. bovis was molecularly detected is Haemaphysalis megaspinosa in cattle [15] and H. longicornis in deer and Japanese wildcats $[39,41,51]$. Recent phylogenetic analyses of A. bovis using 3 genes suggested that it is under the subclade of the genus where A. phagocytophilum and A. platys were found under the Anaplasma genus [14].

A. bovis infection is rare and may be subclinical in nature $[10,11,23]$. In clinical cases, it may be characterized by fluctuating fever lymphadenopathy, depression, and death. Principal manifestations include fever, anorexia, diarrhea, and rarely, central nervous system involvement [52]. Leukopenia and thrombocytopenia may occur [1]. Other possible signs include congestion of oral mucous membranes, decreased amount of stools, absent feces, constipation, dullness, swelling of head, face, ear, jaw and nasal area, lacrimation, mucoid nasal discharge, purulent nasal discharge, syncope, unthriftiness, and emaciation [42]. Some cattle found positive in Japan showed mild to severe anemia, mild leukocytosis and thrombocytopenia, but coinfections with Anaplasma sp. Japan and Theileria sp. are confounding factors which may have also caused the hematologic findings [11].

Diagnosis of $A$. bovis is usually by blood smear [8] or molecular methods [14]. Morulae are usually found in monocytes of infected cattle [53], however, no morulae in blood smears of $A$. bovis - positive cattle in Japan - were observed [11]. It may also be detected in blood films or organ smears, particularly lungs and liver [42]. Complete blood count can be performed as anemia and thrombocytopenia can also be seen [10]. On the other hand, molecular detection provides a reliable method in detecting A. bovis. Among which is the 16S rRNA gene-based nested polymerase chain reaction (nPCR) [39]. The same with A. phagocytophilum, thin slide films from liver, kidney, spleen, lungs, and peripheral blood should be prepared for microscopic examination at necropsy [54].

\section{A. phagocytophilum}

The bacterium $A$. phagocytophilum is the recently designated name replacing three species of granulocytic bacteria, Ehrlichia phagocytophila, Ehrlichia equi and the agent of human granulocytic ehrlichiosis, now known as human granulocytic anaplasmosis (HGA) $[55,56]$. It is the agent of pasture fever or tick-borne fever of ruminants [57]. It is also known to infect humans and horses in the US, Europe [11] and some parts of the Middle East and Asia [58]. This pathogen is known to be highly adaptive to several vectors, hosts and seasonal variations [59]. The bacterium infects blood cells, although no studies have shown direct tropism to neutrophils in cattle as compared to humans [16]. HGA was first described in 1993. The potential threat of HGA to public health has been increasingly recognized in the United States and several European countries [43]. Ixodid ticks and H. megaspinosa can be important in the transmission of $A$. phagocytophilum in animals $[13,15]$. Ohashi et al. [60] suggested that Haemaphysalis formosensis, $H$. longicornis, and Ixodes ovatus may be associated with HGA in Japan.

DNA fragments of $A$. phagocytophilum were first reported in cattle on Yonaguni Island, Okinawa, Japan in 2006 [11]. It was later detected in cattle and sika deer in Hokkaido $[10,11,39,61]$ and wild sika deer in Shizuoka, Japan [48]. Coinfection with Borrelia and Rickettsia spp. has also been reported in Thoroughbred horses in Hidaka district, Hokkaido [62]. Recently, 2 cases of HGA in 2013 [60] and additional 4 cases in 2014 [63] were confirmed in Japan. Infected patients showed fever, chills, headache, and malaise. A. phagocytophilum usually causes a disease in humans characterized by fever, headache, myalgia, leukopenia, anemia, and thrombocytopenia [54]. In ruminants, TBF primarily affects neutrophils and other granulocytes [23], which may develop to a severe febrile reaction, bacteremia and leukopenia due to neutropenia, lymphocytopenia, and thrombocytopenia within a week of exposure to a tick bite [64]. Reduced milk production in cattle can also be observed [65]. Growth rate can also be affected. Mortality is generally low but secondary infection can lead to death in some patients [23]. Subclinical infection has also been documented [66]. In Japan, infected animals can be asymptomatic [10], 
although a recent canine case showed clinical signs, including anorexia, fever, thrombocytopenia, neutropenia and high levels of liver enzyme activity and C-reactive protein [67]. Coinfection of A. phagocytophilum with other tick-borne pathogens may confound the observed clinical signs [49]. A. phagocytophilum can be detected in cattle without any sign of infection but is actually maintaining a persistent subclinical state. The severity of the infection may be influenced by several factors, including the variants involved, coinfection with other pathogens, age, immune status, host condition and environment (climate and management) $[55,66]$.

In diagnosing $A$. phagocytophilum infection, clinical signs and blood smears are unreliable as the disease can be persistent and subclinical in humans and animals with no indications in the smears $[55,66,68]$. If visible, inclusion bodies may be seen in the neutrophils [69]. Blood in anticoagulant should be obtained for hematologic testing. In Giemsa-stained thin blood films, Anaplasma spp. appears as dense, homogeneously staining blue-purple inclusions $0.3-1.0 \mu \mathrm{m}$ in diameter. However, it may be impossible to recognize infected blood cells by the traditional Giemsa staining method due to the low amount of infected cells. At necropsy, thin slide films from liver, kidney, spleen, lungs, and peripheral blood should also be prepared for microscopic examination [53].

Chronically infected carriers may be identified with a fair degree of accuracy by serologic testing. However, DNA-based detection methods are most useful in species and strain differentiation tests [64]. Serological examination by immunofluorescence assay and PCR was used in France to detect $A$. phagocytophilum in cattle [70]. Some also utilize competitive enzyme-linked immunosorbent assay using Msp5 and monoclonal anti-Msp5, like the case in Sicily, Italy [71]. This assay is recommended by the International Office of Epizootics, otherwise known as Office International des Epizooties, for the serological diagnosis of bovine anaplasmosis, but was however shown to be cross-reactive among $A$. marginale, A. centrale, A. ovis, and A. phagocytophilum [72]. Kawahara et al. [39] stressed that the absence of cross protection among this Anaplasma spp. elucidate the potential difficulty in diagnosing Anaplasma spp. infections by serological tests and that molecular diagnosis of Anaplasma infection is more reliable. Ohashi et al. [60] suggested the use of propagation in THP-1 and HL60 cells for serodiagnosis to avoid misdiagnosis of infection in humans. Species-specific nPCR is also a reliable method in the molecular detection of the pathogen [10]. The 16S rRNA nPCR assay [39] is currently among the common methods of confirmation in Japan and other countries.

Different strains may infect animals and humans. High genetic diversity in the 16S rRNA and Msp4 genes of A. phagocytophilum strains can be observed [73]. A. phagocytophilum strains can have different tropism, in which a strain from one animal may not cause disease in another species. Hence, with increasing reports of dissimilar genotypes from different regions of the globe, defining distinct phenotypes and using nomenclature that appropriately clarifies the distinctions are important [74]. It can be implicated that different variants may exist within the same herd, and even simultaneously within the same animal. Variants may behave differently and interact in the mammalian host [55].

\section{Anaplasma sp. Japan}

In Japan, a potentially novel Anaplasma sp. closely related to A. phagocytophilum was detected [12]. It is also reported as "AP-sd" in wild brown bears and rodents in Hokkaido, Japan [75]. Several past studies have reported its detection as A. phagocytophilum despite low sequence similarities, including that of Wu et al. [48] where this species was detected in wild sika deer in Shizuoka, Japan using primers by Kawahara et al. [39] and classified it as A. phagocytophilum (deer strain). Detection of a potentially novel Anaplasma species detected from ticks and deer with diverse $\mathrm{p} 44 / \mathrm{msp} 2$ gene sequences were also reported in several studies [57,76-78]. Based on the results of these studies, it may represent a new species because of its low sequences similarities with the citrate synthase ( $g l t A)$, heat shock operon (groESL) and $16 \mathrm{~S}$ rRNA genes, and the results using several methods of phylogenetic analysis $[12,49,57,75]$. To further validate the novelty, additional characterization using the $\mathrm{ftsZ}$ and $\mathrm{p} 44 / \mathrm{msp} 2$ gene can be performed [75,79]. On the other hand, molecular methods have been developed to detect this species based on the gltA [13] and grOESL genes [14]. In addition, a reverse line blot hybridization based on the 16S rRNA gene was developed [61].

The genus Anaplasma can be pathogenic to humans and animals. Due to public health implications, continuous research in Japan is needed to monitor its epidemiology and distribution. Coinfection of Anaplasma spp. with other pathogens, including Mycoplasma, Theileria or Babesia spp., can also be possible due to common vectors and may have a clinical impact on the diseased animal [18,80-82]. Recently, Anaplasma DNA was detected in milk from goats and sheep [83] in Japan. It may be worthwhile to investigate its presence in the milk of dairy cattle in Japan because of its possible effects to production. On the other hand, further studies might be needed to establish the novelty and pathogenesis of the potentially novel Anaplasma species in Japan.

\section{Conclusion}

There are several Anaplasma spp. that are of veterinary importance in Japan. The presence of these species must be monitored because of its potential impact to animal and human health. 


\section{Authors' Contributions}

APY drafted the manuscript and HI collected the literatures and information about the related researches in Japan. Both authors contributed in incorporating their insights in the manuscript. Both authors read and approved the final manuscript.

\section{Acknowledgments}

The authors would like to thank the University of the Philippines Cebu for the research publication grant and Mr. Cyrill John P. Godinez for the manuscript editing.

\section{Competing Interests} interests.

The authors declare that they have no competing

\section{References}

1. Brouqui, P. and Matsumoto, K. (2007) Bacteriology and phylogeny of anaplasmataceae. In: Raoult, D. and Parola, P., editors. Rickettsial Diseases. Informa Healthcare Inc., New York, NY, USA. p179-198.

2. Dumler, J.S., Barbet, A.F., Bekker, C.P., Dasch, G.A., Palmer, G.H., Ray, S.C., Rikihisa, Y. and Rurangirwa, F.R. (2001) Reorganization of genera in the families Rickettsiaceae and Anaplasmataceae in the order Rickettsiales: Unification of some species of Ehrlichia with Anaplasma, Cowdria with Ehrlichia and Ehrlichia with Neorickettsia, descriptions of six new species combinations and designation of Ehrlichia equi and 'HGE agent' as subjective synonyms of Ehrlichia phagocytophila. Int. J. Syst. Evol. Microbiol., 51: 2145-2165.

3. Ybañez, A.P., Sashika, M. and Inokuma, H. (2014) The phylogenetic position of Anaplasma bovis and inferences on the phylogeny of the genus Anaplasma. J. Vet. Med. Sci., 76: 307 .

4. Razmi, G.R., Dastjerdi, K., Hossieni, H., Naghibi, A., Barati, F. and Aslani, M.R. (2006) An epidemiological study on Anaplasma infection in cattle, sheep, and goats in Mashhad suburb, Khorasan Province, Iran. Ann. N. Y. Acad. Sci., 1078: 479-481.

5. Kuttler, K.L. (1984) Anaplasma infections in wild and domestic ruminants: A review. J. Wildl. Dis., 20: 12-20.

6. Haigh, J.C., Gerwing, V., Erdenebaatar, J. and Hill, J.E. (2008) A novel clinical syndrome and detection of Anaplasma ovis in Mongolian reindeer (Rangifer tarandus). J. Wildl. Dis., 44: 569-577.

7. Kubo, S., Tateno, M., Ichikawa, Y. and Endo, Y. (2015) A molecular epidemiological survey of Babesia, Hepatozoon, Ehrlichia and Anaplasma infections of dogs in Japan. J. Vet. Med. Sci., 77: 1275-1279.

8. Sakamoto, L., Ichikawa, Y., Sakata, Y., Matsumoto, K. and Inokuma, H. (2010) Detection of Anaplasma bovis DNA in the peripheral blood of domestic dogs in Japan. Jpn. J. Infect. Dis., 63: 349-352.

9. Inokuma, H., Fujii, K., Okuda, M., Onishi, T., Beaufils, J.P., Raoult, D. and Brouqui, P. (2002) Determination of the nucleotide sequences of heat shock operon groESL and the citrate synthase gene (gltA) of Anaplasma (Ehrlichia) plays for phylogenetic and diagnostic studies. Clin. Diagn. Lab. Immunol., 9: 1132-1136.

10. Jilintai, S.N., Hayakawa, D., Suzuki, M., Hata, H., Kondo, S., Matsumoto, K., Yokoyama, N. and Inokuma, H. (2009) Molecular survey for Anaplasma bovis and Anaplasma phagocytophilum infection in cattle in a pastureland where Sika deer appear in Hokkaido, Japan. Jpn. J. Infect. Dis., 62: 73-75.

11. Ooshiro, M., Zakimi, S., Matsukawa, Y., Katagiri, Y. and
Inokuma, H. (2008) Detection of Anaplasma bovis and Anaplasma phagocytophilum from cattle on Yonaguni Island, Okinawa, Japan. Vet. Parasitol., 154: 360-364.

12. Ybañez, A.P., Matsumoto, K., Kishimoto, T. and Inokuma, H. (2012) Molecular analyses of a potentially novel Anaplasma sp. closely related to Anaplasma phagocytophilum in Sika deer in Japan. Vet. Microbiol., 157: 232-236.

13. Ybañez, A.P., Matsumoto, K., Kishimoto, T., Yokoyama, N. and Inokuma, H. (2012) Dual presence of Anaplasma phagocytophilum and its closely related Anaplasma sp. In Ixodid ticks in Hokkaido, Japan, and their specific molecular detection. J. Vet. Med. Sci., 74: 1551-1560.

14. Ybañez, A.P., Tagawa, M., Matsumoto, K., Kishimoto, T., Yokoyama, N. and Inokuma, H. (2013) Specific molecular detection of Anaplasma sp. closely related to Anaplasma phagocytophilum in ixodid ticks and cattle in a pastureland in Hokkaido, Japan. Vector Borne Zoonotic Dis., 13: 6-11.

15. Yoshimoto, K., Matsuyama, Y., Matsuda, H., Sakamoto, L., Matsumoto, K., Yokoyama, N. and Inokuma, H. (2010) Detection of Anaplasma bovis and Anaplasma phagocytophilum DNA from Haemaphysalis megaspinosa in Hokkaido, Japan. Vet. Parasitol., 168: 170-172.

16. Aktas, M., Altay, K. and Dumanli, N. (2011) Molecular detection and identification of Anaplasma and Ehrlichia species in cattle from Turkey. Ticks Tick Borne Dis., 2: 62-65.

17. Ybañez, A.P., Sivakumar, T., Battsetseg, B., Battur, B., Altangerel, K., Matsumoto, K., Yokoyama, N. and Inokuma, H. (2013) Specific molecular detection and characterization of Anaplasma marginale in Mongolian cattle. $J$. Vet. Med. Sci., 75: 399-406.

18. Ybañez, A.P., Sivakumar, T., Ybañez, R.H.D., Vincoy, M.R.B., Tingson, J.A., Perez, Z.O., Gabotero, S.R., Buchorno, L.P., Inoue, N., Matsumoto, K. and Inokuma, H. (2013) Molecular survey of bovine vector-borne pathogens in Cebu, Philippines. Vet. Parasitol., 196: 13-20.

19. Ybañez, A.P., Ybañez, R.H.D., Claveria, F.G., Cruzflores, M.J., Xuenan, X., Yokoyama, N. and Inokuma, H. (2014) High genetic diversity of Anaplasma marginale detected from Philippine cattle. J. Vet. Med. Sci., 76: 1009.

20. Moumouni, P.F.A., Aboge, G.O., Terkawi, M.A., Masatani, T., Cao, S., Kamyingkird, K., Jirapattharasate, C., Zhou, M., Wang, G., Liu, M., Iguchi, A., Vudriko, P., Ybañez, A.P., Inokuma, H., Shirafuji-Umemiya, R., Suzuki, H. and Xuenan, X. (2015) Molecular detection and characterization of Babesia bovis, Babesia bigemina, Theileria species and Anaplasma marginale isolated from cattle in Kenya. Parasit. Vectors, 8: 1-14.

21. Ybañez, A.P., Sivakumar, T., Ybañez, R.H.D., Ratilla, J.C., Perez, Z.O., Gabotero, S.R., Hakimi, H., Kawazu, S.I., Matsumoto, K., Yokoyama, N. and Inokuma, H. (2013) First molecular characterization of Anaplasma marginale in cattle and Rhipicephalus (Boophilus) microplus ticks in Cebu, Philippines. J. Vet. Med. Sci., 75: 27-36.

22. Kocan, K.M., de la Fuente, J., Blouin, E.F., Coetzee, J.F. and Ewing, S.A. (2010) The natural history of Anaplasma marginale. Vet. Parasitol., 167: 95-107.

23. Inokuma, H. (2007) Vectors and reservoir host of anaplasmataceae. In: Raoult, D. and Parola, P., editors. Rickettsial Diseases. Informa Healthcare Inc., New York, NY, USA. p199-212.

24. da Silva, J.B., André, M.R. and Machado, R.Z. (2016) Low genetic diversity of Anaplasma marginale in calves in an endemic area for bovine anaplasmosis in the state of São Paulo, Brazil. Ticks Tick Borne Dis., 7: 20-25.

25. Ooshiro, M., Zakimi, S., Matsukawa, Y., Yafuso, M., Katagiri, Y. and Inokuma, H. (2009) Anaplasma marginale infection in a Japanese black cow 13 years after eradication of Rhipicephalus (Boophilus) microplus in Okinawa, Japan. Vet. Parasitol., 160: 351-355.

26. Nakamura, Y., Shimizu, S., Minami, T. and Ito, S. (1988) Enzyme-linked immunosorbent assay using solubilised 
antigen for detection of antibodies to Anaplasma marginale. Trop. Anim. Health Prod., 20: 259-266.

27. Iwakami, S., Ichikawa, Y. and Inokuma, H. (2014) A nationwide survey of ixodid tick species recovered from domestic dogs and cats in Japan in 2011. Ticks Tick Borne Dis., 5: 771-779.

28. Nakamura, Y., Kawazu, S. and Minami, T. (1991) Analysis of protein compositions and surface protein epitopes of Anaplasma centrale and Anaplasma marginale. J. Vet. Med. Sci., 53: 73-79.

29. Zakimi, S., Tsuji, N. and Fujisaki, K. (1994) Protein analysis of Anaplasma marginale and Anaplasma centrale by two-dimensional polyacrylamide gel electrophoresis. J. Vet. Med. Sci., 56: 1025-1027.

30. Ybañez, A.P. (2013) First report on Anaplasma platys infection in a dog in the Philippines. Iran. J. Vet. Med., 7: 227-231.

31. Inokuma, H., Raoult, D. and Brouqui, P. (2000) Detection of Ehrlichia platys DNA in brown dog ticks (Rhipicephalus sanguineus) in Okinawa Island, Japan. J. Clin. Microbiol., 38: 4219-4221.

32. Ybañez, A.P., Perez, Z.O., Gabotero, S.R., Yandug, R.T., Kotaro, M. and Inokuma, H. (2012) First molecular detection of Ehrlichia canis and Anaplasma platys in ticks from dogs in Cebu, Philippines. Ticks Tick Borne Dis., 3: 288-293.

33. Inokuma, H., Brouqui, P., Drancourt, M. and Raoult, D. (2001) Citrate synthase gene sequence: A new tool for phylogenetic analysis and identification of Ehrlich. J. Clin. Microbiol., 39: 3031-3039.

34. Inokuma, H., Terada, Y., Kamio, T., Raoult, D. and Brouqui, P. (2001) Analysis of the 16S rRNA gene sequences of Anaplasma centrale and its phylogenetic relatedness to other Ehrlich. Clin. Diagn. Lab. Immunol., 8: 241-244.

35. Motoi, Y., Satoh, H., Inokuma, H., Kiyuuna, T., Muramatsu, Y., Ueno, H. and Morita, C. (2001) First detection of Ehrlichia platys in dogs and ticks in Okinawa, Japan. Microbiol. Immunol., 45: 89-91.

36. Unver, A., Rikihisa, Y., Kawahara, M. and Yamamoto, S. (2003) Analysis of 16S rRNA gene sequences of Ehrlichia canis, Anaplasma platys, and Wolbachia species from canine blood in Japan. Ann. N. Y. Acad. Sci., 990: 692-698.

37. Inokuma, H., Beppu, T., Okuda, M., Shimada, Y. and Sakata, Y. (2003) Epidemiological survey of Anaplasma platys and Ehrlichia canis using ticks collected from dogs in Japan. Vet. Parasitol., 115: 343-348.

38. Decaro, N., Carelli, G., Lorusso, E., Lucente, M.S., Greco, G., Lorusso, A., Radogna, A., Ceci, L. and Buonavoglia, C. (2008) Duplex real-time polymerase chain reaction for simultaneous detection and quantification of Anaplasma marginale and Anaplasma centrale. J. Vet. Diagn. Invest., 20: 606-611.

39. Kawahara, M., Rikihisa, Y., Lin, Q., Isogai, E., Tahara, K., Itagaki, A., Hiramitsu, Y. and Tajima, T. (2006) Novel genetic variants of Anaplasma phagocytophilum, Anaplasma bovis, Anaplasma centrale, and a novel Ehrlichia sp. in wild deer and ticks on two major islands in Japan. Appl. Environ. Microbiol., 72: 1102-1109.

40. Masuzawa, T., Uchishima, Y., Fukui, T., Okamoto, Y., Muto, M., Koizumi, N. and Yamada, A. (2011) Detection of Anaplasma phagocytophilum from wild boars and deer in Japan. Jpn. J. Infect. Dis., 64: 333-336.

41. Lee, M.J. and Chae, J.S. (2010) Molecular detection of Ehrlichia chaffeensis and Anaplasma bovis in the salivary glands from Haemhaphysalis longicornis ticks. Vector Borne Zoonotic Dis., 10: 411-413.

42. Worthington, R.W. and Bigalke, R.D. (2001) A review of the infectious diseases of African wild ruminants. Onderstepoort J. Vet. Res., 68: 291-323.

43. Grzeszczuk, A., Barat, N.C., Bakken, J.S. and Dumler, J.S. (2007) 16 anaplasmosis in humans. In: Raoult, D. and Parola, P., editors. Rickettsial Diseases. Informa Healthcare Inc., New York, NY, USA. ases, p 223.
44. Sasaki, H., Ichikawa, Y., Sakata, Y., Endo, Y., Nishigaki, K., Matsumoto, K. and Inokuma, H. (2012) Molecular survey of Rickettsia, Ehrlichia, and Anaplasma infection of domestic cats in Japan. Ticks Tick Borne Dis., 3: 308-311.

45. Sashika, M., Abe, G., Matsumoto, K. and Inokuma, H. (2011) Molecular survey of Anaplasma and Ehrlichia infections of feral raccoons (Procyon lotor) in Hokkaido, Japan. Vector Borne Zoonotic Dis., 11: 349-354.

46. Tateno, M., Nishio, T., Sakuma, M., Nakanishi, N., Izawa, M., Asari, Y., Okamura, M., Maruyama, S., Miyama, T.S., Setoguchi, A. and Endo, Y. (2013) Molecular epidemiologic survey of Bartonella, Ehrlichia, and Anaplasma infections in Japanese Iriomote and Tsushima leopard cats. J. Wildl. Dis., 49: 646-652.

47. Tateno, M., Sunahara, A., Nakanishi, N., Izawa, M., Matsuo, T., Setoguchi, A. and Endo, Y. (2015) Molecular survey of arthropod-borne pathogens in ticks obtained from Japanese wildcats. Ticks Tick Borne Dis., 6: 281-289.

48. Wu, D., Wuritu, Yoshikawa, Y., Gaowa, Kawamori, F., Ikegaya, A., Ohtake, M., Ohashi, M., Shimada, M., Takada, A., Iwai, K. and Ohashi, N. (2015) A molecular and serological survey of Rickettsiales bacteria in wild Sika deer (Cervus nippon nippon) in Shizuoka prefecture, Japan: High prevalence of Anaplasma species. Jpn. J. Infect. Dis., 68(5): 434-437.

49. Ybañez, A.P., Kobayashi, Y., Yokoyama, N. and Inokuma, H. (2014) Clinico-pathological findings of a Hereford cow infected with Anaplasma bovis, A. phagocytophilum, and the potentially novel Anaplasma species. Bull. Soc. Franco Jpn. Sci. Vet., 25: 1-8.

50. Ybanez, A.P., Tagawa, M., Sakade, M., Kurauchi, Y., Sasaki, M. and Inokuma, H. (2014) Detection of DNA fragments of Anaplasma bovis from a Hokkaido brown bear (Ursus arctos yesoensis) in Japan. Bull. Soc. Franco Jpn. Sci. Vet., 24: 1-6.

51. Lee, M., Yu, D., Yoon, J., Li, Y., Lee, J. and Park, J. (2009) Natural co-infection of Ehrlichia chaffeensis and Anaplasma bovis in a deer in South Korea. J. Vet. Med. Sci., 71: 101-103.

52. Jilintai, S.N., Matsumoto, K., Hayakawa, D., Suzuki, M., Hata, H., Kondo, S., Yokoyama, N. and Inokuma, H. (2008) Serological and molecular survey of Rickettsial infection in cattle and Sika deer in a pastureland in Hidaka District, Hokkaido, Japan. Jpn. J. Infect. Dis., 61: 315-317.

53. Wanduragala, L. and Ristic, M. (1993) Anaplasmosis. Rickettsial and Chlamydial Diseases of Domestic Animals. Pergamon Press, Oxford. p65-87.

54. Kahn, C.M. (2008) Merck Veterinary Manual. $10^{\text {th }}$ Revised ed. Merck and Co., White House Station, New Jersey.

55. Aktas, M. and Özübek, S. (2015) Bovine anaplasmosis in Turkey: First laboratory confirmed clinical cases caused by Anaplasma phagocytophilum. Vet. Microbiol., 178: $246-251$.

56. Woldehiwet, Z. (2010) The natural history of Anaplasma phagocytophilum. Vet. Parasitol., 167: 108-122.

57. Stuen, S. (2007) Anaplasma phagocytophilum - The most widespread tick-borne infection in animals in Europe. Vet. Res. Commun., 31: 79-84.

58. Ohashi, N., Inayoshi, M., Kitamura, K., Kawamori, F., Kawaguchi, D., Nishimura, Y., Naitou, H., Hiroi, M. and Masuzawa, T. (2005) Anaplasma phagocytophilum-infected ticks, Japan. Emerg. Infect. Dis., 11: 1780-1783.

59. Stuen, S., Granquist, E.G. and Silaghi, C. (2013) Anaplasma phagocytophilum - A widespread multi-host pathogen with highly adaptive strategies. Front. Cell Infect. Microbiol., 3: $1-33$.

60. Ohashi, N., Gaowa, Wuritu, Kawamori, F., Wu, D., Yoshikawa, Y., Chiya, S., Fukunaga, K., Funato, T., Shiojiri, M., Nakajima, H., Hamauzu, Y., Takano, A., Kawabata, H., Ando, S. and Kishimoto, T. (2013) Human granulocytic anaplasmosis, Japan. Emerg. Infect. Dis., 19: $289-292$ 
61. Murase, Y., Konnai, S., Hidano, A., Githaka, N.W., Ito, T., Takano, A., Kawabata, H., Ato, M., Tajima, T., Tajima, M., Onuma, M., Murata, S. and Ohashi, K. (2011) Molecular detection of Anaplasma phagocytophilum in cattle and Ixodes persulcatus ticks. Vet. Microbiol., 149: 504-507.

62. Ybañez, A.P., Fumio, S., Nambo, Y., Fukui, T., Masuzawa, T., Ohashi, N., Matsumoto, K., Kishimoto, T. and Inokuma, H. (2013) Survey on tick-borne pathogens in Thoroughbred horses in the Hidaka district, Hokkaido, Japan. J. Vet. Med. Sci., 75: 11-15.

63. Gaowa, Yoshikawa, Y., Ohashi, N., Wu, D., Kawamori, F., Ikegaya, A., Watanabe, T., Saitoh, K., Takechi, D., Murakami, Y., Shichi, D., Aso, K. and Ando, S. (2014) Anaplasma phagocytophilum antibodies in humans, Japan, 2010-2011. Emerg. Infect. Dis., 20: 508-509.

64. Woldehiwet, Z. (2008) Immune evasion and immunosuppression by Anaplasma phagocytophilum, the causative agent of tick-borne fever of ruminants and human granulocytic anaplasmosis. Vet. J., 175: 37-44.

65. Torina, A. and Caracappa, S. (2007) Anaplasmosis in cattle in Italy. Vet. Res. Commun., 31: 73-78.

66. Noaman, V. and Shayan, P. (2009) Molecular detection of Anaplasma phagocytophilum in carrier cattle of Iran-first documented report. Iran. J. Microbiol., 1: 37-42.

67. Fukui, Y., Fukui, Y., Yoshimura, K. and Inokuma, H. (2016) The reported first case of canine Anaplasma phagocytophilum infection in Japan. J. Jpn. Vet. Med. Assoc., 69: 97-100.

68. Dumler, J.S., Choi, K., Garcia-Garcia, J.C., Barat, N.S., Scorpio, D.G., Garyu, J.W., Grab, D.J. and Bakken, J.S. (2005) Human granulocytic anaplasmosis and Anaplasma phagocytophilum. Emerg. Infect. Dis., 11: 1828-1834.

69. Stuen, S., Oppegaard, A.S., Bergstrom, K. and Moum, T. (2005) Anaplasma phagocytophilum infection in North Norway: The first laboratory confirmed case. Acta Vet. Scand., 46: 167.

70. Matsumoto, K., Joncour, G., Davoust, B., Pitel, P., Chauzy, A., Collin, E., Morvan, H., Vassallo, N. and Brouqui, P. (2006) Anaplasma phagocytophilum infection in cattle in France. Ann. N. Y. Acad. Sci., 1078: 491-494.

71. Torina, A., Alongi, A., Naranjo, V., Estrada-Peña, A., Vicente, J., Scimeca, S., Marino, A.M.F., Salina, F., Caracappa, S. and de la Fuente, F. (2008) Prevalence and genotypes of Anaplasma species and habitat suitability for ticks in a Mediterranean ecosystem. Appl. Environ. Microbiol., 74: 7578-7584

72. Dreher, U.M., Hofmann-Lehmann, R., Meli, M.L., Regula, G., Cagienard, A.Y., Stärk, K.D., Doherr, M.G., Filli, F., Hässig, M., Braun, U. and Kocan, K.M. (2005) Seroprevalence of anaplasmosis among cattle in Switzerland in 1998 and 2003: No evidence of an emerging disease. Vet. Microbiol., 107: 71-79.

73. Torina, A., Alongi, A., Naranjo, V., Scimeca, S., Nicosia, S., Di Marco, V., Caracappa, S., Kocan, K.M. and De La
Fuente, J. (2008) Characterization of Anaplasma infections in Sicily, Italy. Ann. N. Y. Acad. Sci., 1149: 90-93.

74. Foley, J.E., Nieto, N.C. and Foley, P. (2009) Emergence of tick-borne granulocytic anaplasmosis associated with habitat type and forest change in northern California. Am. J. Trop. Med. Hyg., 81: 1132-1140.

75. Moustafa, M.A., Lee, K., Taylor, K., Nakao, R., Sashika, M., Shimozuru, M. and Tsubota, T. (2015) Molecular characterization and specific detection of Anaplasma species (AP-sd) in sika deer and its first detection in wild brown bears and rodents in Hokkaido, Japan. Infect. Genet. Evol., 36: 268-274.

76. Gaowa, Ohashi, N., Aochi, M., Wuritu, Wu, D., Yoshikawa, Y., Kawamori, F., Honda, T., Fujita, H., Takada, N., Oikawa, Y., Kawabata, H., Ando, S. and Kishimoto, T. (2013) Rickettsiae in ticks, Japan, 2007-2011. Emerg. Infect. Dis., 19: 338-340.

77. Gaowa, Wuritu, Wu, D., Yoshikawa, Y., Ohashi, N., Kawamori, F., Sugiyama, K., Ohtake, M., Ohashi, N., Yamamoto, S., Kitano, T., Takada, N. and Kawabata, H. (2012) Detection and characterization of $\mathrm{p} 44 / \mathrm{msp} 2$ transcript variants of Anaplasma phagocytophilum from naturally infected ticks and wild deer in Japan. Jpn. J. Infect. Dis., 65: 79-83.

78. Wuritu, Ozawa, Y., Gaowa, Kawamori, F., Masuda, T., Masuzawa, T., Fujita, H. and Ohashi, N. (2009) Structural analysis of a $\mathrm{p} 44 / \mathrm{msp} 2$ expression site of Anaplasma phagocytophilum in naturally infected ticks in Japan. J. Med. Microbiol., 58: 1638-1644.

79. Lee, K.N., Padmalayam, I., Baumstark, B., Baker, S.L. and Massung, R.F. (2003) Characterization of the ftsZ gene from Ehrlichia chaffeensis, Anaplasma phagocytophilum, and Rickettsia rickettsii, and use as a differential PCR target. DNA Cell Biol., 22: 179-186.

80. Sivakumar, T., Tagawa, M., Yoshinari, T., Ybañez, A.P., Igarashi, I., Ikehara, Y., Hata, H., Kondo, S., Matsumoto, K., Inokuma, H. and Yokoyama, N. (2012) PCR detection of Babesia ovata from cattle reared in Japan and clinical significance of coinfection with Theileria orientalis. J. Clin. Microbiol., 50: 2111-2113.

81. Tagawa, M., Ybañez, A.P., Matsumoto, K., Yokoyama, N. and Inokuma, H. (2013) Interference between Theileria orientalis and hemotropic Mycoplasma spp. (hemoplasmas) in grazing cattle. Vet. Parasitol., 195: 165-168.

82. Tagawa, M., Ybañez, A.P., Matsumoto, K., Yokoyama, N. and Inokuma, H. (2012) Prevalence and risk factor analysis of bovine hemoplasma infection by direct PCR in Eastern Hokkaido, Japan. J. Vet. Med. Sci., 74: 1171-1176.

83. Zhang, Y., Lv, Y., Cui, Y., Wang, J., Cao, S., Jian, F., Wang, R., Zhang, L. and Ning, C. (2016) First molecular evidence for the presence of Anaplasma DNA in milk from sheep and goats in China. Parasitol. Res., 115(7): 2789-2789. 